\title{
Perbandingan Dua Metode Estimasi Pajanan Pestisida di Tempat Kerja
}

\author{
Nurhayati Prihartono
}

\begin{abstract}
Abstrak
Informasi yang valid tentang pajanan masa lalu mungkin sulit didapat dari wawancara individu. Peran ahli seperti higiene industri atau pertanian dalam mengestimasi pajanan pestisida dengan menggunakan jenis pekerjaan dapat meningkatkan validitas data pajanan. Penelitian ini bertujuan membandingkan pajanan pestisida ditempat kerja yang ditentukan berdasarkan laporan individu dan ahli, serta mempelajari pola perbedaan tingkat pajanan dari kedua metode tersebut. Laporan individu berasal dari studi kasus kontrol tentang anemia aplastik di Thailand. Estimasi ahli digunakan untuk menentukan tingkat pajanan terhadap 4 jenis pestisida pada setiap 476 jenis pekerjaan. Instrumen standar dibuat berdasarkan probabilitas pajanan, frekuensi, intensitas dan keyakinan diri dalam menentukan pajanan. Penelitian ini menemukan kesesuaian yang buruk tentang pajanan yang ditentukan oleh kedua metode. Petani padi merupakan kelompok pekerja terbesar yang dinyatakan terpajan ke empat pestisida oleh ahli, tetapi hampir semua petani padi tidak melaporkan keterpajanan tersebut. Ada perbedaan dalam melaporkan pajanan: kelompok kasus, pria, usia muda, dan pekerja yang mempunyai penghasilan tinggi cenderung melaporkan pajanan. Dengan ketidakyakinan estimasi pajanan dari kedua metode ini, maka gabungan pajanan yang berasal dari ahli dan laporan individu akan meningkatkan kegunaan kedua metode dan meningkatkan validitas pajanan.
\end{abstract}

Kata kunci : Pestisida, pajanan, estimasi

\begin{abstract}
Obtaining valid information on past exposures from personal interview may be difficult. The role of experts such as industrial hygienists or agronomists in estimating pesticide exposures could improve the validity of data. The aims of this study are to compare occupational pesticides exposures determined by self-reports and experts, and to examine the discrepancies patterns of exposure ratings obtained by two methods. Self-report exposure information was derived from a case-control study of aplastic anemia in Thailand. Expert judgments were used to assign levels of exposure toward 4 different pesticides among 476 job titles. A standardized instrument was developed based on exposure probability, frequency, intensity and confidence rating. There was a poor appropriateness on pesticide exposure ratings obtained by two methods. Expert cited that grain farmers were the most exposed group among job titles from four pesticides; however, almost grain farmers denied the exposures. There was a discrepancy in reporting the exposure; case groups, youth, male and higher incomes were more likely to report the exposures. Due to the uncertainty of exposure estimation from the two methods, combining estimation both of expert and self-report may enhance the utility of both methods and improve the validity of exposure estimation.
\end{abstract}

Key words : Pesticides, exposure, estimation 
Pada studi kasus kontrol, informasi tentang pajanan masa lalu biasanya didapatkan dari wawancara dengan subyek penelitian. Namun, kemungkinan sulit mendapatkan informasi pajanan masa lalu dari wawancara individu yang valid. Reliabilitas dan validitas laporan individu pada kohort pekerja telah diteliti pada beberapa tempat kerja yang berbeda. ${ }^{1-5}$ Sehubungan dengan pajanan pestisida di pertanian, informasi tentang beberapa kategori pestisida dapat diingat dengan akurat oleh pekerja. ${ }^{2-4}$ Namun, informasi tentang jenis pestisida yang spesifik, seperti organochlorines, kurang dilaporkan. ${ }^{3-4}$ Penggunaan ahli seperti ahli higiene industri atau ahli pertanian untuk mengestimasi pajanan pestisida dengan menggunakan jenis pekerjaan disarankan sebagai metode alternatif yang dapat meningkatkan validitas data pajanan. ${ }^{6-8}$ Keuntungan utama metode ini adalah ahli hanya menentukan pajanan pada pekerjaan dan tidak mengetahui status kasus atau kontrol. Dengan demikian, misklasifikasi pajanan yang differential tidak mungkin terjadi. ${ }^{6}$ Dilain pihak, hal ini juga berarti riwayat individual hilang. Penentuan pajanan terhadap pekerjaan oleh ahli akan lebih efektif pada pekerjaan yang merupakan determinan kuat dan variabilitas individu yang relatif rendah.

Beberapa peneliti telah membandingkan pajanan yang ditentukan oleh ahli dan yang dilaporkan oleh individu pada studi kasus kontrol, dan menemukan kesesuain yang bervariasi (Kappa scores bervariasi dari $-0,05$ sampai 0,94 ) yang tergantung pada populasi studi, metode assessment, dan bahan kimia. ${ }^{7}$ Benke, ${ }^{8}$ menemukan kesesuaian pajanan pestisida yang cukup antara penilaian ahli dan laporan individu.

Pada penelitian ini dilakukan perbandingan estimasi pajanan yang ditentukan oleh ahli higiene industri dan laporan individu dalam suatu studi kasus kontrol tentang anemia aplastik (AA) di Thailand. Tujuan penelitian ini adalah, pertama, untuk mengetahui kesesuaian pajanan pestisida yang ditentukan oleh ahli dan laporan individu. Kedua, mengevaluasi pola perbedaan dalam estimasi pajanan yang berasal dari kedua metode ini untuk mengetahui alasan ketidaksesuaian.

\section{Metode}

Penelitian ini mempelajari pajanan pestisida organophosphate, carbamate, organochlorine dan paraquat di tempat kerja yang dilaporkan oleh pekerja dan yang ditentukan oleh ahli hygiene industri. Data tentang pajanan yang dilaporkan berasal dari studi kasus-kontrol tentang AA di Thailand. Penelitian dilakukan di daerah urban Bangkok, Khonkaen dan Songkla yang sebagian besar dari daerah rural, di bagian utara dan selatan Thailand. Kasus berasal dari rumah sakit dan kontrol diseleksi dari pasien yang ada di rumah sakit yang sama dengan kasus. Untuk setiap kasus pada penelitian ini, diseleksi paling sedikit empat kontrol yang mempunyai jenis kelamin dan umur yang sama dengan kasus sewaktu di diagnosis.

Pengumpulan data pertama dilakukan pada periode 1989 -1994. Terdapat 284 kasus AA dan 1174 kontrol. Penelitian diperpanjang sampai dengan tahun 2002, didapat tambahan 257 kasus dan 1087 kontrol. ${ }^{9}$ Pada saat wawancara, ditanyakan kepada subyek penelitian "Apakah pernah bekerja dalam kurun waktu 6 bulan sebelum ke rumah sakit?" Informasi tentang pajanan ditempat kerja didapatkan dari 2001 subyek yang bekerja. Informasi ini termasuk jenis pekerjaan, jenis industri, dan lama bekerja. Penelitian ini menggunakan modifikasi dari kode jenis pekerjaan terkait dengan industri. ${ }^{10}$ Pada mereka yang bekerja ditanyakan lebih lanjut apakah terpajan terhadap pestisida, benzena, thinner, perekat, dan solvent lainnya.

\section{Evaluasi Pajanan oleh Ahli}

Penelitian lanjutan berupa pengumpulan data oleh tim ahli dilakukan pada tahun 2005. Pajanan dievaluasi oleh suatu tim yang terdiri dari tiga ahli hygiene industri yang sudah berpengalaman di Thailand. Untuk setiap jenis pekerjaan kasus dan kontrol, dua ahli hygiene industri secara mandiri menentukan status pajanan dan tingkat pajanan terhadap setiap pestisida yang diteliti. Sebelumnya, para ahli tersebut mendapat pelatihan menggunakan pedoman scoring yang khusus dibuat untuk penelitian ini. Pertemuan lanjutan dilakukan untuk mendiskusikan tingkat pajanan yang berbeda antara kedua ahli dan kemudian mendapatkan kesepakatan tentang tingkat pajanan secara konsensus.

Setiap pajanan kimia dievaluasi dari tiga dimensi meliputi gabungan probabilitas dan frekuensi (pada analisis disebut probabilitas), intensitas, dan keyakinan diri ahli hygiene industri dalam penentuan pajanan. Sistem scoring ini mengikuti metode yang digunakan oleh Tischer, Dosemeci and Miligi. ${ }^{11-13}$ Sedangkan, pada analisis digunakan probabilitas pajanan yang berasal dari konsensus. Katagori besar atau tingkat probabilitas meliputi tidak ada, apabila pestisida tidak digunakan; rendah, bila pada jenis pekerjaan tersebut pekerja tidak melakukan aplikasi pestisida, tetapi terpajan dari produk pertanian yang sudah mendapatkan treatment pestisida atau tanah dalam jangka waktu 10 hari atau kurang dalam satu tahun; medium, apabila pekerjaan tersebut tidak melakukan aplikasi pestisida tetapi pajanan berasal dari produk pertanian atau tanah dalam jangka waktu lebih dari 10 hari dalam setahun; tinggi, apabila pekerja melakukan aplikasi pestisida pada pekerjaan tersebut dalam 10 hari atau kurang setahun; dan sangat tinggi bila pekerja melakukan aplikasi pestisida pada pekerjaan tersebut dalam jangka waktu lebih dari 10 hari setahun. 


\section{Analisis Data}

Untuk membandingkan dua metode pengumpulan data ini dilakukan analisis agreement (kesesuaian) dengan menghitung Kappa scores. ${ }^{14}$

Tingkat kesesuaian pada statistik Kappa biasanya diinterpretasikan sebagai berikut (15): $>0,80=$ "Sangat baik" ; 0,61 - 0,80 = "baik"; 0,41 - 0,60 = "cukup baik "; $0,21-0,40=$ "cukup" ; $<0,21=$ "buruk". Data pajanan yang dilaporkan oleh pekerja dikategorisasikan menjadi dua, yaitu ya (terpajan) atau tidak (tidak terpajan). Probabilitas pajanan yang ditentukan oleh ahli, pada tahap awalnya dikelompokan dengan tiga cara yang berbeda; (1) terpajan versus tidak; (2) pajanan sedang, tinggi dan sangat tinggi versus pajanan rendah dan tidak terpajan; (3) pajanan tinggi dan sangat tinggi versus pajanan sedang, rendah dan tidak terpajan. Dihipotesiskan bahwa kesesuaian antara kedua metode ini akan semakin baik dengan cara ketiga dibandingkan cara pertama dan kedua karena terfokus pada pajanan yang tinggi, demikian juga kemungkinan misklasifikasi pajanan akan rendah. Untuk mengetahui faktor yang dapat mempengaruhi tingkat agreement yang baik dan yang buruk, dihitung Kappa score antara kedua metode berdasarkan status kasus atau kontrol dan lama bekerja.

Penilaian pajanan oleh ahli berdasarkan pekerjaan akan lebih dapat digunakan untuk memprediksi pajanan daripada yang dilaporkan. Oleh sebab itu, dilakukan analisis tambahan untuk mengetahui perbedaan pada pekerja yang dinyatakan terpajan oleh ahli, tetapi tidak melaporkan terpajan dan pekerja yang melaporkan bahwa mereka terpajan. Untuk analisis ini digunakan pembagian kelompok probabilitas pajanan dengan cara ketiga (pajanan tinggi dan sangat tinggi versus pajanan sedang, rendah dan tidak terpajan).

Subyek yang melaporkan terpajan dan yang tidak melaporkan terpajan (pada mereka yang dikatakan terpajan oleh ahli) dibandingkan berdasarkan status kasus atau kontrol, umur, jenis kelamin, lama bekerja dan pendapatan keluarga. Dalam analisis ini, lama bekerja dibagi dua berdasarkan median lama bekerja, yaitu 360 hari atau kurang lebih 1 tahun. Umur dikategorikan menjadi kurang dari 25 tahun, 25 s/d 59 tahun, dan 60 tahun atau lebih. Jumlah pendapatan keluarga dalam 1 bulan dikategorikan menjadi <1500, 1500-4999, dan $\geq 5000$ baht. Kemudian, dihitung proporsi subyek yang melaporkan pajanan pada pekerjaan yang ditentukan terpajan oleh ahli.

Uji statistik chi-square dilakukan untuk mengetahui perbedaan proporsi subyek pada pekerjaan yang ditentukan terpajan oleh ahli. ${ }^{14}$

\section{Hasil}

Penelitian ini menemukan kesesuaian yang rendah antara pajanan yang dilaporkan oleh subyek individu dan yang ditentukan oleh ahli pada empat jenis pestisida (Lihat Tabel 1). Kesesuaian pajanan antara kedua metode ini sedikit meningkat ketika pajanan yang ditentukan oleh ahli dikelompokan dengan cara pajanan tinggi dan sangat tinggi pada satu kelompok versus sedang/rendah/tidak ada pajanan pada kelompok lain. Hal ini terlihat konsisten untuk semua pestisida yang diteliti. Untuk analisis selanjutnya, digunakan kategori terpajan pajanan tinggi dan sangat tinggi.

Penelitian ini mendapatkan kesesuaian yang lebih tinggi pada kelompok kasus daripada pada kelompok kontrol, demikian pula pada subyek yang bekerja dalam

Tabel 1. Kesesuaian Probabilitas Terpajan Setiap Pestisida antara Ahli dan Laporan Individu

\begin{tabular}{|c|c|c|c|c|c|c|}
\hline \multirow{3}{*}{ Laporan individu } & \multicolumn{6}{|c|}{ Estimasi oleh ahli } \\
\hline & \multicolumn{2}{|c|}{ Terpajan } & \multicolumn{2}{|c|}{$\begin{array}{c}\text { Sedang, Tinggi } \\
\text { Sangat Tinggi }\end{array}$} & \multicolumn{2}{|c|}{$\begin{array}{l}\text { Tinggi, Sangat } \\
\text { Tinggi }\end{array}$} \\
\hline & Tidak & Ya & Tidak & Ya & Tidak & $\overline{Y a}$ \\
\hline \multicolumn{7}{|l|}{ Organophosphate } \\
\hline Tidak & 1283 & 620 & 1381 & 522 & 1459 & 444 \\
\hline $\mathrm{Ya}$ & 6 & 68 & 8 & 66 & 9 & 65 \\
\hline Карра & & 0.12 & & 0.14 & & 0.1 \\
\hline \multicolumn{7}{|l|}{ Carbamate } \\
\hline Tidak & 1040 & 910 & 1361 & 589 & 1392 & 558 \\
\hline $\mathrm{Ya}$ & 4 & 21 & 5 & 20 & 5 & 20 \\
\hline Kappa & & 0.02 & & 0.04 & & 0.04 \\
\hline \multicolumn{7}{|l|}{ Organochlorine } \\
\hline Tidak & 924 & 1038 & 1401 & 561 & 1455 & 507 \\
\hline $\mathrm{Ya}$ & 4 & 10 & 7 & 7 & 7 & 7 \\
\hline Kappa & & 0.005 & & 0.01 & & 0.01 \\
\hline \multicolumn{7}{|l|}{ Paraquat } \\
\hline Tidak & 927 & 996 & 1412 & 511 & 1418 & 505 \\
\hline Ya & 4 & 48 & 7 & 45 & 7 & 45 \\
\hline Kappa & & 0.04 & & 0.10 & & 0.11 \\
\hline
\end{tabular}




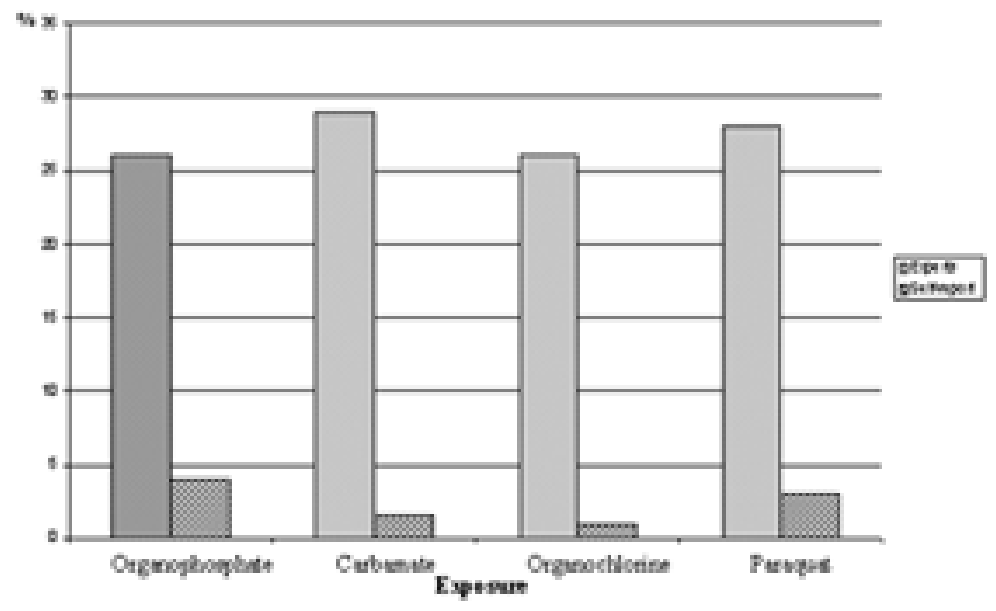

Grafik 1. Prevalens Pajanan dari Laporan Individu dan Estimasi Ahli

Tabel 2. Pajanan Pestisida yang Dilaporkan Pekerja yang Dinilai oleh Ahli Berdasarkan Karakteristik Subyek

\begin{tabular}{|c|c|c|c|c|c|c|c|c|c|c|c|c|c|c|c|c|}
\hline \multirow[t]{3}{*}{ Karakteristik } & \multirow[t]{3}{*}{ Katagori } & \multicolumn{3}{|c|}{ Organophosphate } & \multicolumn{3}{|c|}{ Carbamate } & \multicolumn{3}{|c|}{ Organochlorine } & \multicolumn{3}{|c|}{ Paraquat } & \multicolumn{3}{|c|}{ Empat Pestisida } \\
\hline & & \multirow{2}{*}{$\begin{array}{c}\text { Tidak } \\
\mathbf{N}\end{array}$} & \multicolumn{2}{|c|}{ Ya } & \multirow{2}{*}{$\begin{array}{c}\text { Tidak } \\
\mathrm{N}\end{array}$} & \multicolumn{2}{|c|}{ Ya } & \multirow{2}{*}{$\frac{\text { Tidak }}{\mathrm{N}}$} & \multicolumn{2}{|c|}{ Ya } & \multirow{2}{*}{$\frac{\text { Tidak }}{\mathbf{N}}$} & \multicolumn{2}{|c|}{ Ya } & \multirow{2}{*}{$\frac{\text { Tidak }}{\mathrm{N}}$} & \multicolumn{2}{|c|}{ Ya } \\
\hline & & & $\mathbf{N}$ & $\%$ & & $\mathbf{N}$ & $\%$ & & $\mathbf{N}$ & $\overline{\%}$ & & $\mathbf{N}$ & $\%$ & & $\mathbf{N}$ & $\%$ \\
\hline \multirow[t]{2}{*}{ Status } & Kasus & 107 & 25 & 19 & 133 & 10 & 7 & 128 & 4 & 3 & 128 & 13 & 9 & 105 & 41 & 28 \\
\hline & Kontrol & 337 & 40 & 11 & 425 & 10 & 2 & 379 & 3 & 1 & 377 & 32 & 8 & 372 & 74 & 17 \\
\hline \multirow[t]{3}{*}{ Umur (tahun) } & $<25$ & 27 & 5 & 16 & 38 & 0 & 0 & 34 & 0 & 0 & 37 & 2 & 5 & 34 & 7 & 17 \\
\hline & $25-59$ & 354 & 55 & 13 & 449 & 20 & 4 & 411 & 7 & 2 & 397 & 42 & 10 & 376 & 102 & 21 \\
\hline & $60+$ & 63 & 5 & 7 & 71 & 0 & 0 & 62 & 0 & 0 & 71 & 1 & 1 & 67 & 6 & 8 \\
\hline \multirow{2}{*}{ Jenis kelamin } & Pria & 207 & 35 & 14 & 258 & 18 & 7 & 236 & 5 & 2 & 231 & 31 & 12 & 218 & 69 & 24 \\
\hline & Wanita & 237 & 30 & 11 & 300 & 2 & 1 & 271 & 2 & 1 & 274 & 14 & 5 & 259 & 46 & 15 \\
\hline \multirow{2}{*}{ Lama bekerja } & $\leq 1$ tahun & 246 & 35 & 12 & 330 & 12 & 4 & 282 & 5 & 2 & 291 & 25 & 8 & 290 & 65 & 18 \\
\hline & $>1$ tahun & 195 & 30 & 13 & 224 & 7 & 3 & 222 & 2 & 1 & 211 & 20 & 9 & 183 & 49 & 21 \\
\hline \multirow[t]{3}{*}{ Pendapatan } & $<1500$ & 60 & 6 & 9 & 66 & 3 & 4 & 65 & 1 & 2 & 66 & 5 & 7 & 61 & 10 & 14 \\
\hline & $1500-4999$ & 145 & 19 & 12 & 169 & 4 & 2 & 159 & 3 & 2 & 163 & 10 & 6 & 147 & 30 & 17 \\
\hline & $\geq 5000$ & 235 & 39 & 14 & 318 & 13 & 4 & 278 & 3 & 1 & 271 & 30 & 10 & 265 & 74 & 22 \\
\hline
\end{tabular}

jangka waktu pendek daripada mereka yang sudah lama bekerja.

Faktor yang memungkinkan ketidaksesuaian pajanan antara kedua metode ini adalah pajanan jauh lebih prevalens menurut ahli daripada yang dilaporkan oleh subyek (Lihat Grafik 1). Secara umum, prevalens pajanan yang berasal dari laporan subyek berkisar antara $1 \%$ sampai $4 \%$, sedangkan pajanan yang berasal dari ahli jauh lebih banyak (berkisar dari 26\% sampai 29\%).

Karena hampir semua subyek yang dinyatakan terpajan oleh ahli tidak melaporkan bahwa mereka terpajan, maka diteliti apakah terdapat perbedaan antara yang melaporkan dan yang tidak melaporkan terpajan pada subyek yang dikatakan terpajan oleh ahli (Lihat Tabel 2). Didapatkan kelompok kasus lebih banyak yang melaporkan terpajan pestisida daripada kontrol. Hal ini terlihat pada keempat pestisida. Perbedaan ini terlihat paling kuat untuk pajanan organophosphate: 19\% dari kasus dan $11 \%$ dari kontrol $(\mathrm{p}=0,01)$. Kelompok usia muda lebih banyak yang melaporkan terpajan terhadap pestisida daripada kelompok berusia tua. Kelompok usia tua ( $\geq$ 60 tahun) hanya sedikit ( $8 \%$ ) yang melaporkan terpajan pestisida walaupun pekerjaan mereka oleh ahli dikatakan terpajan ( $\mathrm{p}=0,01$ untuk setiap pestisida). Pria lebih banyak yang melaporkan terpajan daripada wanita $(\mathrm{p}=$ 0,01 untuk setiap pestisida), dan mereka yang berpenghasilan besar lebih banyak yang melaporkan terpajan. Penelitian ini tidak menemukan perbedaan dalam melapor terpajan pada mereka yang bekerja kurang dari 1 tahun dan lebih dari 1 tahun.

Petani padi adalah jenis pekerjaan yang paling banyak diantara jenis pekerjaan yang dikatakan terpajan terhadap semua pestisida oleh ahli (Lihat Tabel 3 ). Jumlahnya antara 73 sampai $83 \%$ dari total subyek yang 
KESMAS, Jurnal Kesehatan Masyarakat Nasional Vol. 4, No. 5, April 2010

Tabel 3. Pajanan yang Dilaporkan oleh Individu pada Pekerjaan yang Dinilai Terpajan oleh Ahli

\begin{tabular}{|c|c|c|c|c|}
\hline \multirow[t]{2}{*}{ Insektisida } & \multirow[t]{2}{*}{ Pekerjaan } & \multirow[t]{2}{*}{ Penilaian Ahli } & \multicolumn{2}{|c|}{ Terpajan berdasarkan Laporan Individu } \\
\hline & & & $\mathbf{N}$ & $\%$ \\
\hline \multirow[t]{5}{*}{ Organophosphate } & Petani padi & 422 & 56 & $13 \%$ \\
\hline & Petani buah/kacang & 28 & 3 & $11 \%$ \\
\hline & Petani tidak dapat diklasifikasikan & 22 & 0 & $0 \%$ \\
\hline & Petani sayuran & 15 & 1 & $7 \%$ \\
\hline & 6 pekerjaan lain* & 22 & 5 & $23 \%$ \\
\hline \multirow{6}{*}{ Carbamate } & Petani padi & 420 & 12 & $3 \%$ \\
\hline & Guru & 39 & 4 & $10 \%$ \\
\hline & Petani buah/kacang & 28 & 1 & $4 \%$ \\
\hline & Petani tidak dapat diklasifikasikan & 22 & 0 & $0 \%$ \\
\hline & Petani sayuran & 15 & 1 & $7 \%$ \\
\hline & 13 pekerjaan lain* & 64 & 2 & $3 \%$ \\
\hline \multirow[t]{5}{*}{ Organochlorine } & Petani padi & 420 & 5 & $1 \%$ \\
\hline & Petani buah/kacang & 28 & 1 & $4 \%$ \\
\hline & Buruh tani & 24 & 0 & $0 \%$ \\
\hline & Petani sayuran & 15 & 1 & $7 \%$ \\
\hline & 10 pekerjaan lain* & 27 & 0 & $0 \%$ \\
\hline \multirow{6}{*}{ Paraquat } & Petani padi & 420 & 33 & $8 \%$ \\
\hline & Petani buah/kacang & 28 & 6 & $21 \%$ \\
\hline & Buruh tani & 24 & 1 & $4 \%$ \\
\hline & Petani tidak dapat diklasifikasikan & 22 & 2 & $9 \%$ \\
\hline & Petani sayuran & 15 & 2 & $13 \%$ \\
\hline & 19 pekerjaan lain* & 41 & 1 & $2 \%$ \\
\hline
\end{tabular}

"pekerjaan yang kurang dari 10 subyek di kelompokan

Tabel 4. Pajanan yang Dilaporkan Individu Pekerjaan yang Dinilai Tidak Terpajan oleh Ahli

\begin{tabular}{llccc}
\hline Insektisida & Pekerjaan & Terpajan & Jumlah Subjek & $\%$ \\
\hline Organophosphate & Pekerja bangunan & 3 & 107 & $3 \%$ \\
& Guru & 3 & 39 & $8 \%$ \\
& Tukang kayu & 1 & 23 & $4 \%$ \\
& Petugas keamanan & 1 & 23 & $4 \%$ \\
Carbamate & Pekerja bangunan jalan & 1 & 16 & $6 \%$ \\
& Pekerja bangunan & 1 & 107 & $1 \%$ \\
& Pekerja toko makanan & 1 & 50 & $2 \%$ \\
& Pekerja pada saluran & 1 & 40 & $2 \%$ \\
Organochlorine & Petugas keamanan & 1 & 23 & $4 \%$ \\
& Manajer/administrasi & 1 & 1 & $100 \%$ \\
& Tidak dapat dikategorikan & 1 & 122 & $1 \%$ \\
& Supir & 1 & 46 & $2 \%$ \\
& Penjual makanan & 1 & 35 & $3 \%$ \\
& Pembantu rumah & 1 & 21 & $5 \%$ \\
& Petugas keamanan & 1 & 23 & $4 \%$ \\
& Pekerja bangunan jalan & 1 & 16 & $6 \%$ \\
& Pemasang pintu/jendela & 1 & 2 & $50 \%$ \\
& Tidak dapat dikategorikan & 1 & 122 & $1 \%$ \\
& Pekerja bangunan & 1 & 107 & $2 \%$ \\
& Pengantar & 2 & 18 & $5 \%$ \\
& Militer & 1 & 13 & $8 \%$ \\
& Pemutar mesin & 1 & 4 & $25 \%$ \\
& Manajer/administrasi & 1 & 1 & $100 \%$ \\
\hline
\end{tabular}

dinyatakan terpajan oleh ahli. Seperti semua pekerjaan yang dinyatakan terpajan oleh ahli, hampir seluruh petani padi mengatakan bahwa mereka tidak terpajan terhadap keempat jenis pestisida. Satu-satunya pekerjaan nonagraris yang berjumlah lebih dari 10 subyek dan dikatakan tepajan terhadap pestisida (carbamates) oleh ahli adalah guru. Terdapat 39 subyek yang bekerja seba- gai guru, hanya 4 orang diantaranya yang melaporkan terpajan oleh carbamates.

Penelitian ini menemukan 7 pekerja yang melaporkan pajanan terhadap organochlorines. Di Thailand, penggunaan organochlorine untuk pertanian telah dilarang sejak tahun 1983, tetapi masih dipakai untuk kontrol hama. Ahli higiene industri menetapkan 4 jenis 
pekerjaan di sektor agraria yang mempunyai pajanan organochlorine, yaitu petani padi, petani buah atau kacang, petani sayuran dan grain laborer. Namun, penentuan pajanan organochlorines oleh ahli tidak jelas, apakah berdasarkan penggunaan organochlorines secara ilegal atau untuk kontrol hama.

Jumlah subyek yang melaporkan pajanan sementara jenis pekerjaan mereka dikatakan tidak ada pajanan oleh ahli hanya sedikit (Lihat Tabel 4). Jenis pekerjaannya pada umumnya adalah bukan di industri pertanian. Dua jenis pekerjaan, pekerja bangunan dan supir, juga ditemukan pada industri pertanian. Beberapa pekerja bangunan melaporkan terpajan terhadap organophosphate, carbamate and paraquat. Ahli higiene industri tidak menetapkan pajanan organophosphate pada guru, tetapi 3 diantara 39 guru melaporkan terpajan terhadap organophosphates.

\section{Pembahasan}

Penelitian dengan desain kasus kontrol ini mendapatkan perbedaan yang besar dalam estimasi prevalens pestisida antara estimasi oleh ahli higiene industri dan yang dilaporkan oleh subyek. Karena tidak ada gold standard yang mana kedua estimasi ini dapat dibandingkan, tidak dapat diambil kesimpulan estimasi mana yang lebih akurat. Mungkin juga hanya sebagian yang benar dari kedua estimasi ini. Ahli higiene industri mempunyai kelebihan dalam melihat sistem pertanian secara menyeluruh dan mengetahui jenis pestisida yang mana digunakan pada tananam tertentu untuk pestisida tertentu. Informasi ini dapat lebih dipercaya dalam mengidentifikasi jenis pestisida yang kemungkinan besar ada. Pajanan yang dilaporkan merupakan pengalaman dari individu pada potongan waktu yang sempit terkait pada penelitian. Namun, disayangkan dapat terjadi bias recall pada laporan individu. Hal ini merupakan salah satu penjelasan dari hasil yang ditemukan bahwa kasus lebih banyak yang melaporkan pajanan daripada kontrol pada pekerjaan yang dinyatakan terpajan oleh ahli (Lihat Tabel 2). Kemungkinan lain adalah pajanan memang benar meningkatkan risiko anemia aplastik, sehingga prevalens pajanan pada kelompok kasus tinggi.

Kesesuaian pajanan yang buruk antara yang dinyatakan oleh ahli dan yang dilaporkan terutama disebabkan karena subyek tidak melaporkan terpajan sementara dia mempunyai pekerjaan yang dinyatakan terpajan oleh ahli. Sebaliknya, subyek melaporkan terpajan pada pekerjaan yang dinyatakan tidak terpajan oleh ahli sangat jarang. Hal serupa telah dilaporkan oleh Benke, ${ }^{8}$ yang mendapati prevalens insektisida yang rendah dari yang dilaporkan $(0,6 \%)$, dibandingkan panel ahli $(3,6 \%)$ dan job exposure matrix $(11,2 \%)$. Apapun alasan perbedaan dalam melaporkan, prevalens pajanan yang sangat rendah yang didapat dari laporan subyek daripada ahli akan menyebabkan kesesuaian yang buruk. Kappa akan selalu rendah bila terdapat perbedaan yang besar pada frekuensi margin. Skor yang berasal dari konsensus bertujuan untuk meningkatkan reliabilitas rating oleh ahli. Ada keterbatasan yang struktural pada penilaian oleh ahli yaitu pemberian tingkat pajanan yang sama untuk semua orang yang mempunyai pekerjaan yang sama, sehingga tidak ada variasi pajanan dalam suatu pekerjaan. Informasi ini hanya dapat diberikan oleh subyek apabila mereka ditanya dan dapat dipercaya memberikan estimasi yang tidak bias. ${ }^{16}$

Kelemahan yang paling besar dari pajanan yang dilaporkan adalah pada umumnya subyek tidak dapat mengidentifikasi pajanan yang sudah lalu, sehingga sensitivitasnya rendah. Beberapa penelitian yang menyelidiki validitas pajanan pestisida pada pekerja secara kohort mendapatkan hasil yang bervariasi. Engel, ${ }^{4}$ mengamati walaupun penggunaan organophosphates dan organochlorines sangat besar pada petani apel, sensitivitasnya berbeda (lebih dari 90\% untuk organophosphate and hanya $70 \%$ untuk organochlorine). Perry, ${ }^{1}$ telah melakukan suatu penelitian pajanan terhadap herbisida pada aplikator pestisida dan mendapatkan sensitivitas yang rendah untuk pajanan yang dilaporkan oleh subyek, yaitu berkisar antara $2 \%$ hingga $77 \%$. Pada penelitian ini informasi tentang pajanan didapat dari wawancara di rumah sakit dan perhatian terhadap pajanan yang sudah lalu mungkin lebih buruk daripada penelitian oleh Perry yang dilakukan di industri yang menghasilkan telur, susu dan keju.

Penelitian ini menemukan kesesuaian yang buruk antara ahli dan yang dilaporkan subyek tentang pajanan pestisida. Penelitian terdahulu yang dilakukan oleh Benke, menemukan kesesuaian yang cukup tentang insektisida (kappa $=0,44)$, dan lebih tinggi dari bahan kimia lainnya. ${ }^{8}$ Tingginya kappa pada kelompok kasus daripada kelompok kontrol pada penelitian ini menyerupai temuan yang didapat oleh Nordstrom dalam penelitian aktivitas fisik ditempat kerja dan carpal tunnel syndrome. ${ }^{17}$

Beberapa faktor berhubungan dengan kecenderungan untuk melaporkan pajanan di kalangan pekerja yang pekerjaannya dinilai terpajan oleh ahli (Tabel 2). Faktor tersebut adalah umur muda, pria, dan berpenghasilan tinggi berkorelasi di dalam populasi. Wanita pada umumnya mempunyai pendapatan yang lebih rendah daripada pria (data tidak diperlihatkan), sehingga faktor tersebut bukanlah suatu fenomena terpisah. Dengan demikian, hasil penelitian ini memberi petunjuk bahwa walaupun hanya sebagian kecil pajanan yang dilaporkan dari pekerjaan yang dinyatakan terpajan oleh ahli, tetapi tidak terjadi secara random. Ada dua kemungkinan penjelasan untuk hal ini yang dapat diidentifikasi: pertama, pola ini memang menggambarkan pajanan yang sebenarnya ber- 
beda, karena perbedaan tugas di pekerjaan antara pria dan wanita, antara pekerja berumur muda dan tua. Pada banyak industri stratifikasi gender dan umur dalam suatu pekerjaan umum dijumpai. Populasi di Thailand bagian Timur Laut lebih banyak etnik Lao-Thai, etnik minoritas di Thailand. Suatu penelitian tentang praktek pertanian di Thailand menemukan bahwa wanita Hmong kurang fasih dalam berbahasa Thai dan kurang memperhatikan bahaya kesehatan kerja. ${ }^{18}$ Kemungkinan yang kedua adalah perbedaan ini mewakili tedensi untuk melapor pajanan, karena bias recall.

\section{Kesimpulan}

Penelitian ini menemukan kesesuaian yang buruk antara pajanan yang diestimasi oleh ahli dan yang dilaporkan oleh subyek. Perbedaan dalam melaporkan pajanan berhubungan dengan status kasus atau kontrol dan faktor sosial ekonomi. Dengan adanya ketidakyakinan dalam estimasi pajanan yang berasal dari kedua metode ini maka menggambungkan kedua estimasi ini dapat meningkatkan penggunaan kedua metode ini dan meningkatkan validitas estimasi pajanan.

\section{Ucapan Terima Kasih}

Ditujukan kepada Dr.David Kaufman yang telah mengijinkan melakukan penelitian lanjutan dari studi anemia aplastik di Thailand. Kepada Dr.David Kriebel dan Dr.Susan Woskie atas masukannya untuk penelitian maupun penulisan. Kepada Anamai Thetkhathuek, PhD, Nalinee Sripaung, PhD dan Chantana Padungtod, MD, DrPH yang telah membantu penelitian ini dalam penilaian pajanan

\section{Daftar Pustaka}

1. Perry MJ, Marbell A, Layde P. Nonpersistent pesticide exposure self-reported versus biomonitoring in farm pesticide applicators. AE. 2006P; 16(9): 701-7.

2. Hoppin JA, Yucel F, Dosemeci M, Sandler DP. Accuracy of self-reported pesticide use duration information from licensed applicators in the agricultural health study. J Expo Anal Environ Epidemiol. 2002; 12: 313-8.

3. Ngowi AVF, Partanen T. Treatment of pesticide poisoning: a problem for health care workers in Tanzania. African Newsletter on Occupatonal Health and Safety. 2002; 12(3): 71-4.
4. Engels LS, Seixas NS, Keifer MC, Longstreth JR WT, Chekoway H. Validity study of self-reported pesticide exposure among orchardists. J Expo Environ Epidemiol. 2001: 11: 358-68.

5. Bond GG, Bodner KM, Sobel W, Shellenberger RJ, Aores GH. Validation of work history obtained from interviews. Am J Epidemiol. 1988; (28): 343-51.

6. Stewart WF, Stewart PA. Occupational case-control studies: I. collecting information on work histories and work-related exposures. Am J Ind Med. 1994; 26: 297-312.

7. Teschke K, Oshan AF, Daniels JL. Occupational exposure assessment in case-control studies: opportunity for improvement. Occup Environ Med . 2002; 59: 575-94.

8. Benke G, Sim M, Frtschi L. Comparison of occupational exposure using three different methods: hygiene panel, job exposure matrix (JEM), and self reports. Appl Occup Environ Hyg. 2001; 16: 84 - 91.

9. Issaragrisil S, Kaufman DW, Anderson T, Chansung K, Leaverton PE, Shapiro S, et al. The epidemiology of aplastic anemia in Thailand. Blood. 2006; 107(4): 1299-307.

10. Hoar SK, Morrison AS, Cole P, Silverman DT. An occupation and exposure linkage system for the study of occupational carcinogenesis. J Occup Med. 1980; 22(11): 722-6.

11. Tischer M, Brendendick-Kamper S, Poppek U. Evaluation of the HSE COSHH essentials exposure predictive model on the basis of BAuA fields studies and existing substance exposure data. Ann Occup Hyg. 2003; 47(7): 557-69.

12. Dosemeci M, Alavanja M, Rowland A, Mage D, Zahm SH, Rothman N, et al. A quantitative approach for estimating exposure to pesticides in the agricultural health study. Ann.Occup.Hyg. 2002; 46: 250-60.

13. Miligi M, Seniori Costantini A, Benvenuti A, Kriebel D, Bolejack V, Tumino R, et al. Occupational exposure to solvents and the risk of lymphomas. Epidemiology. 2006; 17: 52-561.

14. Rosner B. Fundamental of biostatistics. Duxbury. 2000. pp 407-10.

15. Altman DG. Practical statistics for medical student. Chapman and Hall, London; 1991.

16. Stewart P, Rice C, Beatty P, Wilson B, Stewart W, Herrick RF. A qualitative evaluation of questions and responses from five occupational questionnaires developed to assess exposures. Appl Occup Environ Hyg. 2002;17(6): 444-53.

17. Nordstrom DL, Vierkant RA, Layde PM, Smith MJ. Comparison of selfreported and expert-observed physical activity at work in a general population. Am J Ind Med. 1998; 34: 29-35.

18. Kunstadter P, Prapamontol T, Sirirojn B, Sontirat A, Tansuhaj A, Khamboonruang C. Pesticide exposures among Hmong farmers in Thailand. Int J Occup Environ Health 2001;7(4): 313-32. 